\title{
Additive Manufacturing of Monolithic Microwave Dielectric Ceramic Filters via Digital Light Processing
}

\author{
Qingrong Liu ${ }^{1}$, Mingbo Qiu ${ }^{1}$, Lida Shen ${ }^{1, *(\mathbb{D}}$, Chen Jiao $^{1}$, Yun Ye ${ }^{1}$, Deqiao Xie ${ }^{1}{ }^{1}$, \\ Changjiang Wang ${ }^{2} \mathbb{D}$, Meng $X_{\text {iao }}{ }^{3}$ and Jianfeng Zhao ${ }^{1}$ \\ 1 College of Mechanical and Electrical Engineering, Nanjing University of Aeronautics and Astronautics, \\ Nanjing 210016, China; liuqr@nuaa.edu.cn (Q.L.); qiumingbo@nuaa.edu.cn (M.Q.); \\ jiaochen@nuaa.edu.cn (C.J.); yeyun@nuaa.edu.cn (Y.Y.); dqxie@nuaa.edu.cn (D.X.); zhaojf@nuaa.edu.cn (J.Z.) \\ 2 Department of Engineering and Design, University of Sussex, Sussex House, Brighton BN1 9RH, UK; \\ C.J.Wang@sussex.ac.uk \\ 3 Nanjing Institution of Advanced Laser Technology, Nanjing 210038, China; xiaomeng@siom.ac.cn \\ * Correspondence: ldshen@nuaa.edu.cn; Tel.: +86-189-5189-2566
}

Received: 26 August 2019; Accepted: 18 September 2019; Published: 20 September 2019

check for updates

\begin{abstract}
Microwave dielectric ceramics are employed in filters as electromagnetic wave propagation media. Based on additive manufacturing (AM) techniques, microwave dielectric ceramic filters with complex and precise structures can be fabricated to satisfy filtering requirements. Digital light processing (DLP) is a promising AM technique that is capable of producing filters with high accuracy and efficiency. In this paper, monolithic filters made from $\mathrm{Al}_{2} \mathrm{O}_{3}$ and $\mathrm{TiO}_{2}$, with a molar ratio of 9:1 $\left(0.9 \mathrm{Al}_{2} \mathrm{O}_{3}-0.1 \mathrm{TiO}_{2}\right)$, were fabricated by DLP. The difference in the dielectric properties between the as-sintered and post-annealed samples at different temperatures was studied. The experimental results showed that when sintered at $1550{ }^{\circ} \mathrm{C}$ for $2 \mathrm{~h}$ and post annealed at $1000{ }^{\circ} \mathrm{C}$ for $5 \mathrm{~h}, 0.9 \mathrm{Al}_{2} \mathrm{O}_{3}-0.1$ $\mathrm{TiO}_{2}$ exhibited excellent dielectric properties: $\varepsilon_{\mathrm{r}}=12.4, \mathrm{Q} \times \mathrm{f}=111,000 \mathrm{GHz}, \tau_{\mathrm{f}}=+1.2 \mathrm{ppm} /{ }^{\circ} \mathrm{C}$. After comparing the measured results with the simulated ones in the passband from 6.5 to $9 \mathrm{GHz}$, it was concluded that the insertion loss (IL) and return loss (RL) of the filter meet the design requirements.
\end{abstract}

Keywords: microwave dielectric ceramics; filter; additive manufacturing; digital light processing; post annealing; dielectric properties

\section{Introduction}

In recent years, microwave dielectric ceramics have shown great advantages in the development of miniaturization, weight reduction, and integration of filters [1]. Low dielectric constant microwave dielectric ceramics have fast transmission and response speed, high temperature stability in working environment, high signal transmission quality, low transmission loss, and good frequency selectivity. Owing to these superior qualities, they are widely used in $5 \mathrm{G}$ wireless mobile communication, satellite communication, and radar systems.

When the microwave dielectric ceramic is employed on equipment with high communication quality, it is necessary to have a small dielectric constant $\varepsilon_{\mathrm{r}}$, a quality factor $\mathrm{Q}$ as large as possible, and a frequency temperature coefficient $\tau_{\mathrm{f}}$ of near zero in order to meet the requirements of the application. Actually, the microwave communication device is used at different temperatures. If the resonant frequency of the microwave dielectric material changes greatly with temperature, the carrier signal will drift at different temperatures, thereby affecting the performance of the device. It is required that the resonant frequency of the material should hardly change with temperatures. $\mathrm{Mg}_{2} \mathrm{SiO}_{4}, \mathrm{Mg}_{4} \mathrm{Nb}_{2} \mathrm{O}_{9}$, and $\mathrm{Al}_{2} \mathrm{O}_{3}$ are widely studied as common low dielectric constant microwave dielectric ceramics, though the $\mathrm{Q} \times \mathrm{f}$ value of $\mathrm{Al}_{2} \mathrm{O}_{3}$ is significantly higher than that of $\mathrm{Mg}_{2} \mathrm{SiO}_{4}$ and $\mathrm{Mg}_{4} \mathrm{Nb}_{2} \mathrm{O}_{9}$ [2] . 
As a typical low dielectric constant microwave dielectric ceramic, $\mathrm{Al}_{2} \mathrm{O}_{3}$ possesses the qualities of low manufacturing cost, high precision and great thermal conductivity (i.e., $24.5 \mathrm{~W} \mathrm{~m}^{-1} \mathrm{~K}^{-1}$ at room temperature) [3]. Above all, it exhibits outstanding dielectric properties at millimeter wave frequency. Alford reported the microwave dielectric properties of $\mathrm{Al}_{2} \mathrm{O}_{3}: \varepsilon_{\mathrm{r}}=10, \mathrm{Q} \times \mathrm{f}=500,000 \mathrm{GHz}$, and $\tau_{\mathrm{f}}=-60 \mathrm{ppm} /{ }^{\circ} \mathrm{C}$ [4]. However, it also has obvious disadvantages. As mentioned above, the $\tau_{\mathrm{f}}$ of $\mathrm{Al}_{2} \mathrm{O}_{3}$ is relatively large and the sintering temperature is quite high $\left(1600^{\circ} \mathrm{C}\right.$ to $\left.1700{ }^{\circ} \mathrm{C}\right)$, limiting its industrial application. At the same time, $\mathrm{TiO}_{2}$ ceramics have a $\varepsilon_{\mathrm{r}}$ of 100 , a Qf of $48,000 \mathrm{GHz}$, and a positive large $\tau_{\mathrm{f}}$ of $+450 \mathrm{ppm} /{ }^{\circ} \mathrm{C}$ [5]. Therefore, in order to improve the dielectric performance of $\mathrm{Al}_{2} \mathrm{O}_{3}$ ceramics, a certain amount of $\mathrm{TiO}_{2}$ is usually added to form $\mathrm{Al}_{2} \mathrm{O}_{3}-\mathrm{TiO}_{2}$ composite ceramics, allowing a value of $\tau_{\mathrm{f}}$ tending to zero to be obtained. Youshihiro et al. have reported the dielectric properties of the $\mathrm{Al}_{2} \mathrm{O}_{3}-\mathrm{TiO}_{2}$ system, of which $\tau_{\mathrm{f}}$ is nearly zero when the molar ratio of $\mathrm{Al}_{2} \mathrm{O}_{3}$ to $\mathrm{TiO}_{2}$ is 9:1 [6]. Due to different working temperatures, the thermal conductivity of the $\mathrm{Al}_{2} \mathrm{O}_{3}-\mathrm{TiO}_{2}$ system is a problem that needs to be considered. Generally, high thermal conductivity of typical ceramics can be correlated to common features like simple crystal structure, low atomic mass, strong interatomic forces, high atomic packing density, comparable atomic weight differences among the components in the composition, etc. Moreover, the thermal conductivity has a reciprocal relation with the square root of mean atomic mass in the material [7]. It is worth noting that the elements in $0.9 \mathrm{Al}_{2} \mathrm{O}_{3}-0.1$ $\mathrm{TiO}_{2}$ system possess relatively low atomic weight. The melting temperature of $0.9 \mathrm{Al}_{2} \mathrm{O}_{3}-0.1 \mathrm{TiO}_{2}$ is around $1900{ }^{\circ} \mathrm{C}$, which is an indirect indicator of strong interatomic bonding, a prerequisite for high thermal conductivity.

Nowadays, microwave and radio frequency passive devices realized by additive manufacturing (AM) have attracted an increasing amount of attention [8-10]. Different materials can be manufactured via AM, including plastics, metals, and ceramics. The latter has been widely used in filters as dielectric resonators. For components made entirely of ceramics, their surface metalization is achieved by employing electroless nickel/copper plating, thereby avoiding the radiation of the electromagnetic field [11]. A remarkable advantage of AM compared to traditional computer numerical control (CNC) milling technology, is that the processed object is accumulated layer by layer, and the processing cost is theoretically only related to the volume of the object (i.e., the amount of raw materials) and does not consider the complexity of its geometric structure. Therefore, in terms of complex geometric structures, the cost of AM is lower than that of traditional CNC milling technology, making AM technology particularly suitable for manufacturing complex and precise mechanical structures. Typically, molding accuracy and efficiency are unable to be simultaneously achieved, particularly for AM methods. The technique of point-by-point scanning molding using 3D Gel Printing (3DGP) and stereolithography (SLA) methods requires a significant amount of shaping time [12]. Digital light processing (DLP) based on the surface exposure AM method can theoretically avoid this shortcoming and does not require scanning path planning $[13,14]$. Compared with other AM methods, DLP has the characteristics of high precision, small internal size, and fast forming speed. Our team has successfully fabricated bone scaffolds using bio-ceramic material hydroxyapatite via DLP AM technology, which demonstrated the feasibility of the DLP method in manufacturing ceramic materials [15]. This study utilizes DLP AM technology to fabricate microwave dielectric ceramic filters to significantly improve the forming efficiency while also ensuring accuracy.

In this paper, a ceramic suspension with suitable viscosity was prepared using photopolymer, $\mathrm{Al}_{2} \mathrm{O}_{3}$, and $\mathrm{TiO}_{2}$ powders. The designed monolithic microwave dielectric ceramic filter was fabricated by DLP technology. The filter sample was then obtained after post treatment processes, including drying, debinding, sintering, post annealing, and metalization. The effects of sintering temperature and annealing process on the dielectric properties of $0.9 \mathrm{Al}_{2} \mathrm{O}_{3}-0.1 \mathrm{TiO}_{2}$ ceramics were investigated based on the densification, $\mathrm{X}$-ray diffraction (XRD), and microstructure of the samples. The S-parameters and group delay obtained from the actual test were compared with the simulation results, indicating that the manufactured filter meets the design requirements. The research results show that it is feasible to make sophisticated microwave dielectric ceramic filters using DLP AM technology. 


\section{Materials and Methods}

\subsection{Preparation of the Ceramic Suspension}

Figure 1 shows the complete preparation of the microwave dielectric ceramic filter. In this study, a micro-sized, nano-sized spherical $\mathrm{Al}_{2} \mathrm{O}_{3}$ powder and micro-sized spherical TiO $\mathrm{O}_{2}$ powder $\left(\mathrm{Al}_{2} \mathrm{O}_{3} \geq 99.9 \mathrm{wt} \%, \mathrm{TiO}_{2} \geq 99.5 \mathrm{wt} \%\right.$, Chengdu Kewan Intelligent Technology Co., Ltd, Chengdu, China) were used as the starting material with a particle size of $5 \mathrm{~mm}, 500 \mathrm{~nm}$, and $1 \mu \mathrm{m}$, respectively. Table 1 lists the basic physical parameters of the three powders. The $\mathrm{Al}_{2} \mathrm{O}_{3}$ powder of two particle sizes is uniformly mixed at a $1: 1 \mathrm{wt}$ ratio, followed by the $\mathrm{TiO}_{2}$ powder being added to the mixed $\mathrm{Al}_{2} \mathrm{O}_{3}$ powder at a molar wt ratio of 1:9. The premixed solution used to prepare the ceramic suspension consisted of two components: photosensitive resin (Shanghai Ai Rui Technology Co., Ltd, Shanghai, China) and sodium polyacrylate dispersant (Hebei Jinghong Chemical Co., Ltd, Hebei, China). The as-prepared powder was then added to the premixed solution to form the ceramic suspension. After manual premixing, the ceramic suspension was then ball-milled for $12 \mathrm{~h}$ using zirconia balls. The suspension was then degassed for 30 min using a vacuum mixer. In this way, a ceramic suspension with solid content of $45 \%$ could be obtained. In this work, the mixing of the nanopowders and the micropowders was performed in order to create a balance between the viscosity of the ceramic slurry and the density of the sintered body. Previous theoretical and experimental studies have demonstrated that the combination of powders with different particle sizes is an effective method for increasing the volume fraction and reducing the viscosity of the ceramic slurry. Moreover, the density of the sintered body made of powders of different particle sizes is higher than that made of a single particle size powder [16].

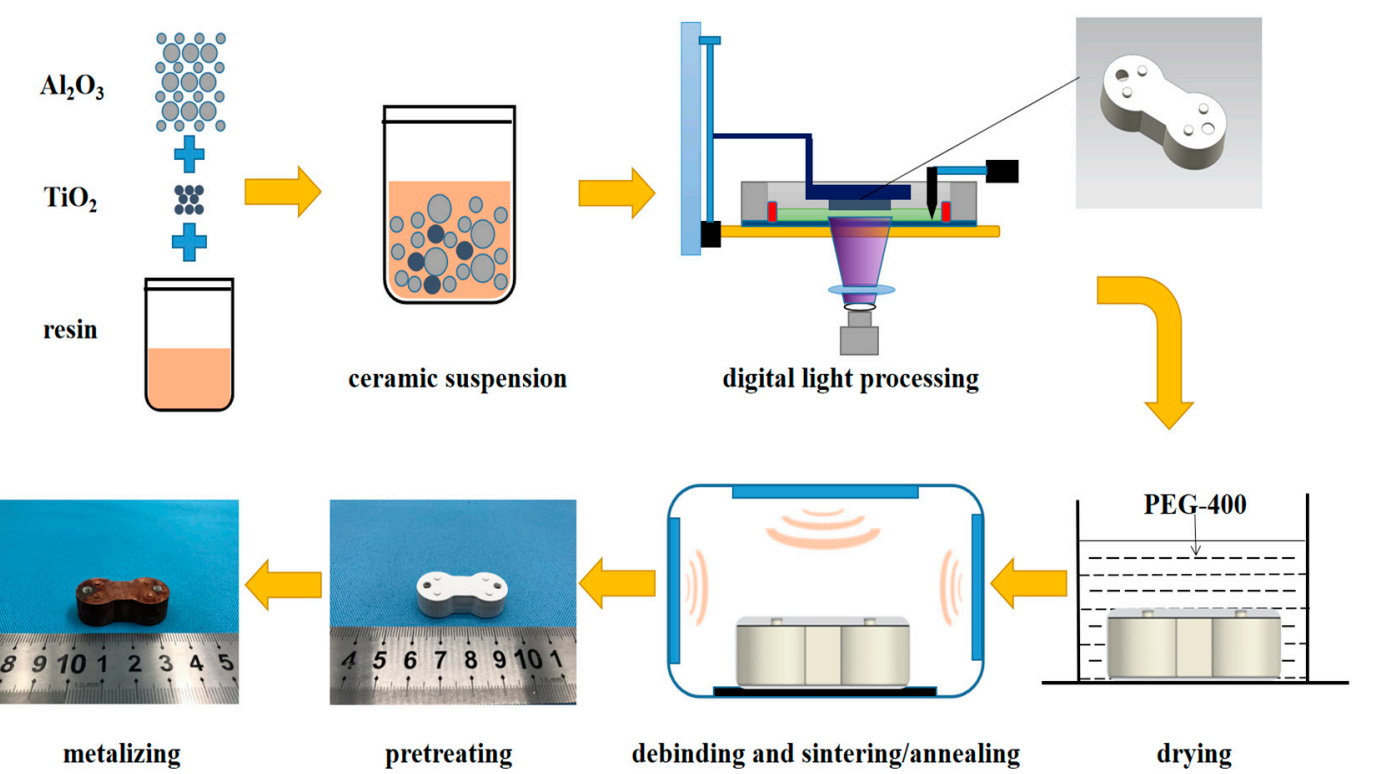

Figure 1. Preparation processes of the microwave dielectric ceramic filter.

Table 1. Characteristic parameters of the raw material.

\begin{tabular}{cccc}
\hline & AL-1 & AL-2 & TiO $_{2}$ \\
\hline D50 $(\mu \mathrm{m})$ & 5 & 0.5 & 2 \\
Density $\left(\mathrm{g} \cdot \mathrm{cm}^{-3}\right)$ & 3.726 & 3.742 & 4.124 \\
Density $\left(\mathrm{g} \cdot \mathrm{cm}^{-3}\right)$ & 2.136 & 10.996 & 13.216 \\
\hline
\end{tabular}

\subsection{Design and Simulation of the Microwave Dielectric Ceramic Filter}

As depicted in Figure 2a, a two-pole transverse magnetic (TM) mode microwave dielectric ceramic filter, in which the fundamental resonance is the $\mathrm{TM}_{01 \delta}$ mode, was designed with the following 
parameters. The center frequency was $8.3 \mathrm{GHz}$ and fractional bandwidth was $1.54 \%$. The height of the filter was $10 \mathrm{~mm}$, whereas the radius of the cylindrical cavity was $7.58 \mathrm{~mm}$. The diameter of the two center posts, acting as resonators, was $3 \mathrm{~mm}$. The thickness of the chamber wall was set to $1 \mathrm{~mm}$, which is convenient for manufacturing and microwave performance testing. Alignment posts were designed to facilitate the placement of Sub-Miniature version A (SMA) connectors for the input and output couplings. After designing the size parameters of the filter, a High Frequency Structure Simulator (HFSS) was utilized for simulation, which is based on the finite element method (FEM). The essential steps are listed below.

(1) The geometric model of the filter was first created using 3D Modeler according to the size parameters of the design, which are shown in Figure 2b.

(2) The microwave dielectric material selected in the design was set to have a $\varepsilon_{\mathrm{r}}$ of 12.4.

(3) According to the defined port and boundary conditions, excitation type was a lumped port excitation, boundary type was set to be Perfect E.

(4) Then the simulation frequency range needed to be defined. The center frequency of the designed filter was $8.3 \mathrm{GHz}$, and the simulation frequency range was $6.5-9 \mathrm{GHz}$.

(5) After the above operations, the simulation step was run.

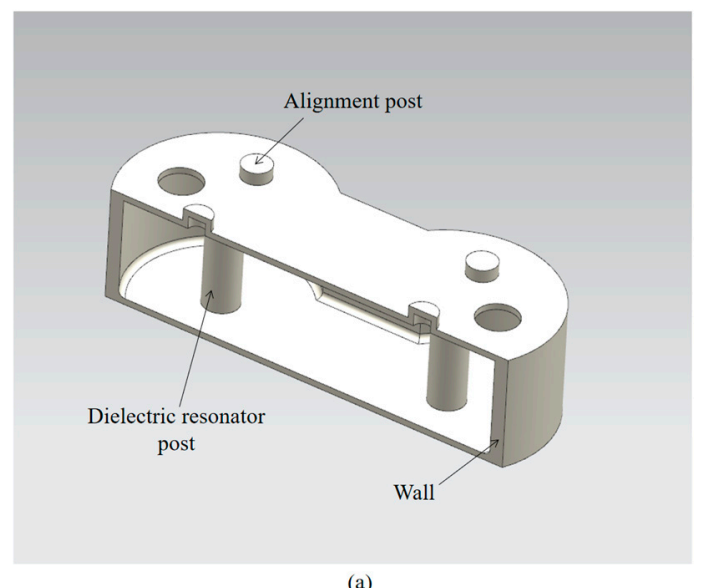

(a)

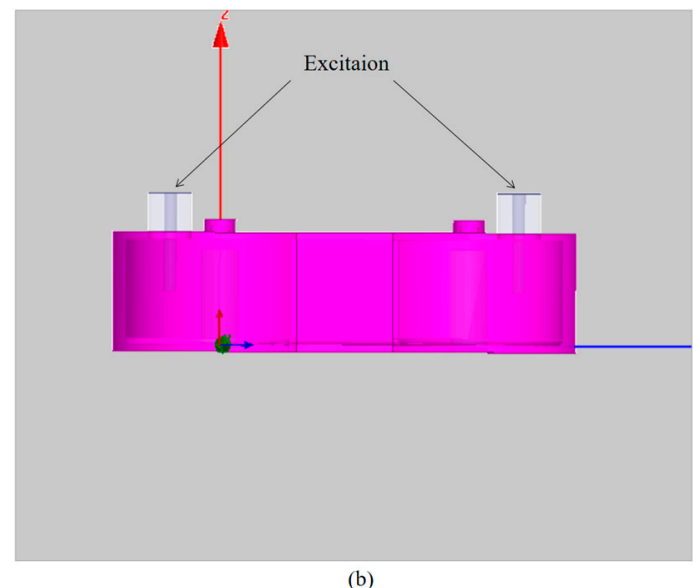

(b)

Figure 2. Prototype of the designed microwave dielectric ceramic filter. (a) Structure geometry and (b) simulation layout.

\subsection{Fabrication and Post Treatment of the Filters}

Firstly, the 3D model was created using the Unigraphics NX (UG) software (Siemens PLM Software, Plano, TX, USA), and then the Magics software was employed to generate the supporting structure and to slice the parts. The final data was output as a stereolithography (STL) file, which was then imported into the DLP printer. The DLP printing machine was developed by the Nanjing University of Aeronautics and Astronautics. The light source of the DLP printer can emit ultraviolet light at a wavelength of $405 \mathrm{~nm}$. The size of the experimental molding substrate was $60 \mathrm{~mm} \times 80 \mathrm{~mm}$, and its $\mathrm{z}$ axis accuracy was $10 \mu \mathrm{m}$. As shown in Figure 3, selective scanning of the ceramic suspension by ultraviolet light during the molding process cures each layer pattern. After the first layer is cured, the forming platform moves upward and the ceramic suspension was recoated on the cured surface with a blade. The second layer is then cured using the same process. These steps are repeated until the entire ceramic body is finally obtained. 

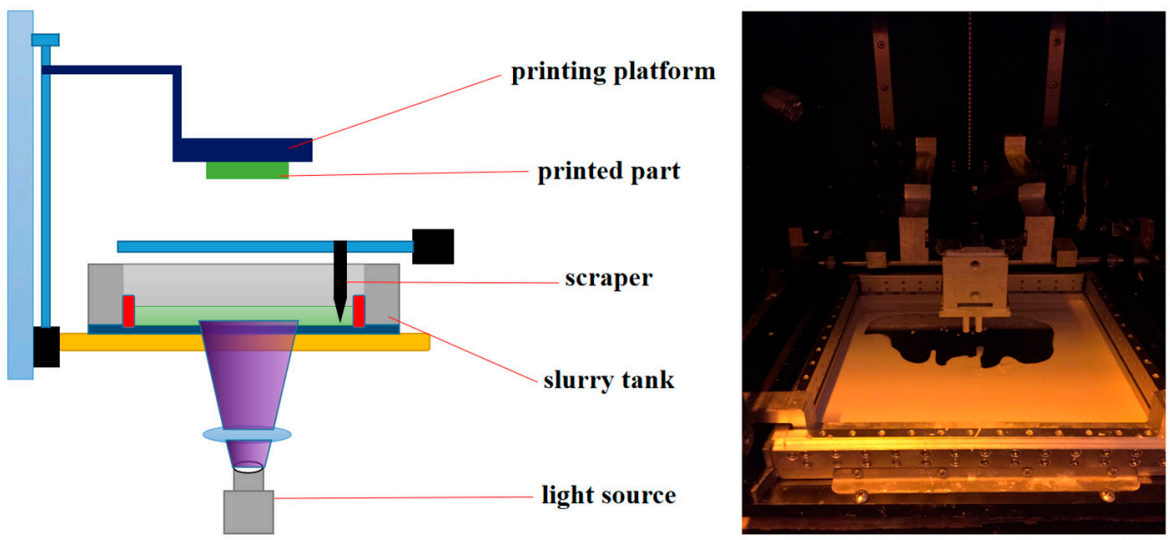

Figure 3. Schematic view of the printing process.

The printed ceramic body then underwent ultrasonic cleaning in alcohol, followed by running tap water. After that, the residual water in the body had to be removed by drying. An innovative method is to use PEG-400. For the PEG-based extraction process, the sample was immersed in PEG-400, which was expected to result in a uniform extraction rate in all directions [17]. With the purpose of removing the polymer binder and achieving densification, the sample then underwent two thermal processes: debinding and sintering. A two-step debinding method was adopted in this work. The first stage under vacuum debinding was to slow down the pyrolysis rate, and a second debinding in the air was conducted to ensure complete removal of residual carbon. The debinding stage is the most time-consuming step since the resin needs to be slowly removed to prevent cracking. As shown in Figure 4, according to the phase diagram of $\mathrm{Al}_{2} \mathrm{O}_{3}-\mathrm{TiO}_{2}$, the two reacted at $1200{ }^{\circ} \mathrm{C}$ to form the $\mathrm{Al}_{2} \mathrm{TiO}_{5}$ phase. The appearance of $\mathrm{Al}_{2} \mathrm{TiO}_{5}$ depreciates the properties of $\mathrm{Al}_{2} \mathrm{O}_{3}-\mathrm{TiO}_{2}$ microwave dielectric ceramics [6]. Accordingly, the annealing process is required to eliminate the adverse effects of $\mathrm{Al}_{2} \mathrm{TiO}_{5}$. The binder-removed samples were sintered at temperatures of $1450{ }^{\circ} \mathrm{C}, 1500{ }^{\circ} \mathrm{C}, 1550{ }^{\circ} \mathrm{C}$, and $1600{ }^{\circ} \mathrm{C}$. They were then kept at the highest temperature for $2 \mathrm{~h}$, and then annealed at $1000{ }^{\circ} \mathrm{C}$ for $5 \mathrm{~h}$. The sintered $0.9 \mathrm{Al}_{2} \mathrm{O}_{3}-0.1 \mathrm{TiO}_{2}$ ceramic part shrinks, and the shrinkage coefficient of the sample was measured to be approximately $25 \%$. This signifies that the original model must be scaled up accordingly before manufacturing. In order to shield the filter, a $10 \mu \mathrm{m}$ copper layer was applied to the external surfaces.

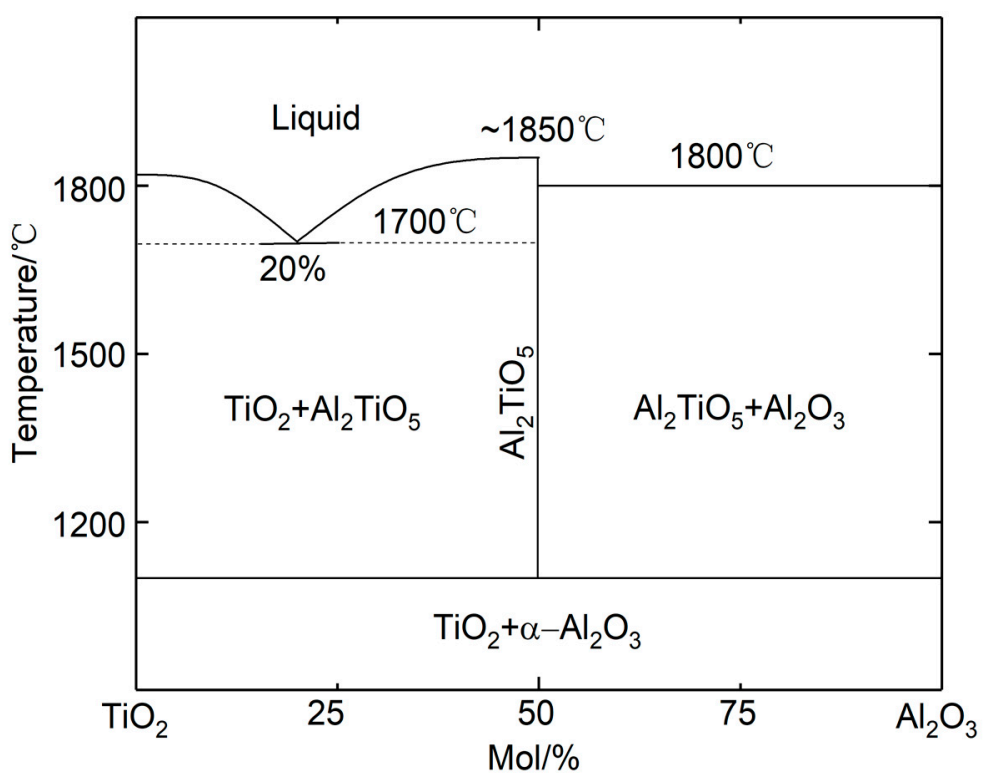

Figure 4. Phase diagram of $\mathrm{TiO}_{2}-\mathrm{Al}_{2} \mathrm{O}_{3}$. 


\subsection{Measurements and Characterizations}

The microstructure of the sintered sample was characterized by scanning electron microscope (SEM) (S-4800; Hitachi Instruments, Tokyo, Japan). The relative density was determined by the Archimedes' displacement method. The samples at different temperatures were investigated by XRD (DMAX2500PC; Rigaku Corp., Tokyo, Japan) under the following conditions: $10^{\circ}-80^{\circ}$ diffraction angle, CuK $\alpha$ radiation $(\lambda=1.5406 \AA), 40 \mathrm{kV}, 100 \mathrm{~mA}, 0.02^{\circ}$ step width, and $5^{\circ} / \mathrm{min}$ scanning speed. Qf and $\varepsilon_{\mathrm{r}}$ were measured by a network analyzer (Agilent 8722E) (Keysight, Santa Rosa, CA, USA) using a pair of parallel conducting $\mathrm{Ag}$ and $\mathrm{Cu}$ plates in the $\mathrm{TE}_{011}$ mode of modified Hakki and Coleman's resonator method $[18,19]$. The Agilent $8722 \mathrm{ET}$ network analyzer and incubator were used to measure $\tau_{\mathrm{f}}$ at the temperature range of $20^{\circ} \mathrm{C}-80^{\circ} \mathrm{C}$. The calculation formula is:

$$
\tau_{f}=\frac{1}{f_{20}} \cdot \frac{f_{80}-f_{20}}{80-20}
$$

in which $f_{80}$ and $f_{20}$ are the resonant frequencies at $80{ }^{\circ} \mathrm{C}$ and $20{ }^{\circ} \mathrm{C}$, respectively. The designed microwave dielectric ceramic filter was simulated by HFSS, and its insertion loss, return loss, and group delay were obtained. As shown in Figure 5, two SMA connectors were mounted on the fabricated filter structure to enable testing of their microwave performance with the network analyzer (Keysight N5247A) (Keysight, Santa Rosa, CA, USA).

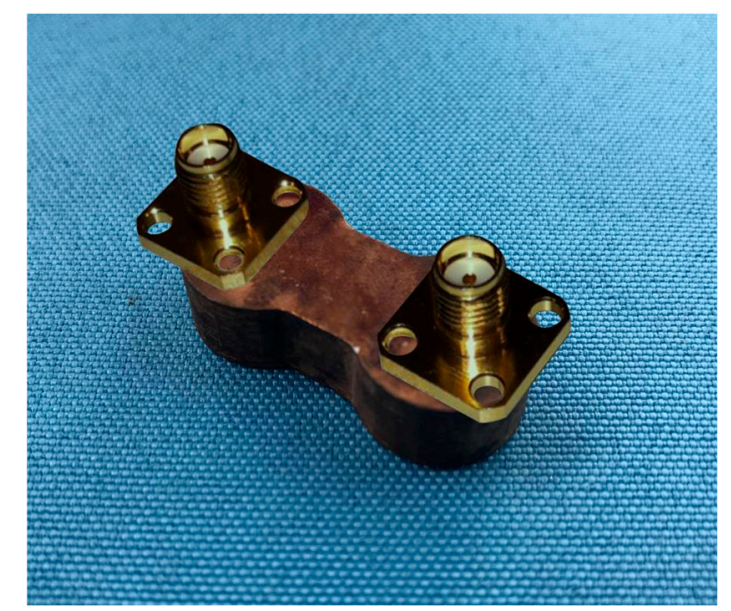

Figure 5. Schematic diagram of mounting position of two SMA connectors on the filter.

\section{Results}

\subsection{The Results of the Dielectric Properties}

Figure 6 shows the changing trend in the dielectric properties of the $0.9 \mathrm{Al}_{2} \mathrm{O}_{3}-0.1 \mathrm{TiO}_{2}$ system, and Table 2 lists the accurate values of the $0.9 \mathrm{Al}_{2} \mathrm{O}_{3}-0.1 \mathrm{TiO}_{2}$ system before and after annealing at different sintering temperatures. As shown in Figure 6a, with the increase in sintering temperature, the $Q f$ value of the $0.9 \mathrm{Al}_{2} \mathrm{O}_{3}-0.1 \mathrm{TiO}_{2}$ ceramics first increases and then decreases, reaching a maximum at $1550{ }^{\circ} \mathrm{C}$. However, the post-annealed sample had an increase of about $30,000 \mathrm{GHz}$ in Qf value compared to the as-sintered sample at the same temperature. From the point of view of ceramic technology, as long as there exists consistent structure, high density, and uniform grain growth, impurities and defects are reduced. As such, the dielectric loss $\tan \delta$ can be reduced, thus resulting in an improved $Q$ value. In the Discussion section, dielectric properties will be analyzed based on the relative density, microstructure, and crystal structure of the sample. 


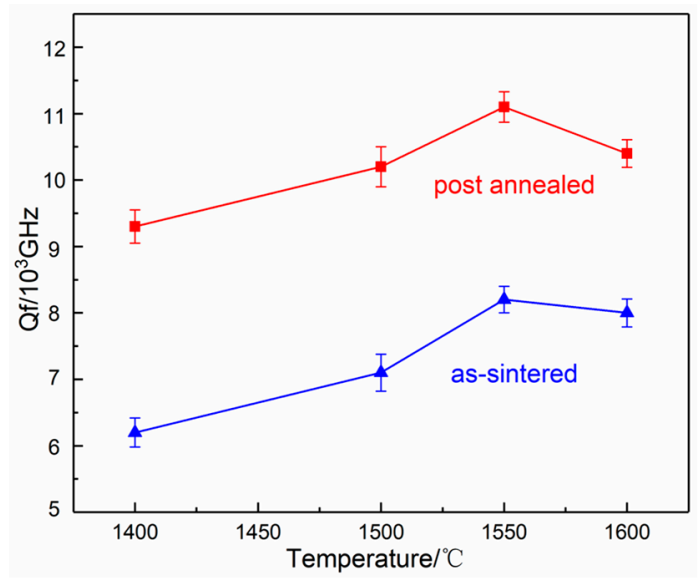

(a)

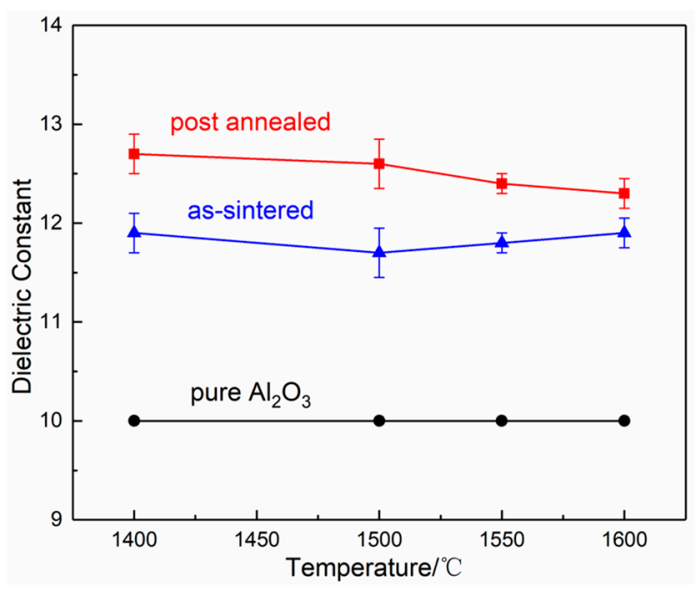

(b)

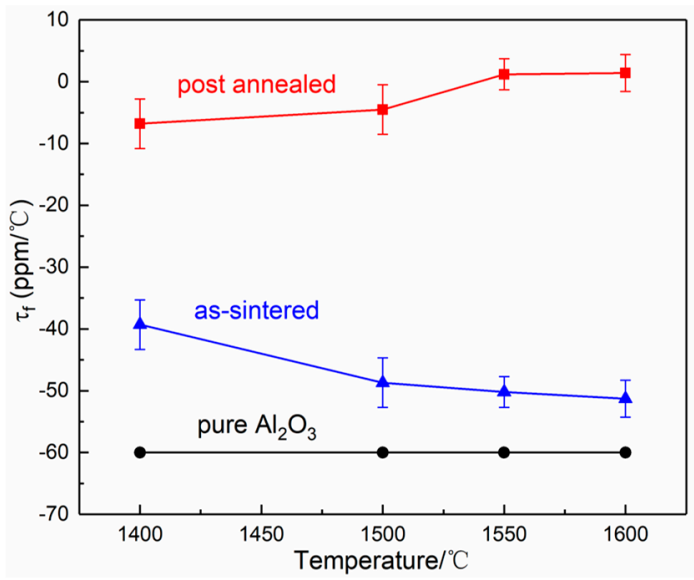

(c)

Figure 6. (a) Qf, (b) $\varepsilon_{\mathrm{r}}$, and (c) $\tau_{\mathrm{f}}$, of $0.9 \mathrm{Al}_{2} \mathrm{O}_{3}-0.1 \mathrm{TiO}_{2}$ ceramics sintered at different temperatures for $2 \mathrm{~h}$ and annealed at $1000{ }^{\circ} \mathrm{C}$ for $5 \mathrm{~h}$. The results of pure $\mathrm{Al}_{2} \mathrm{O}_{3}$ are also plotted in $(\mathbf{b}, \mathbf{c})$ for comparison [3].

Table 2. Microwave dielectric properties of $0.9 \mathrm{Al}_{2} \mathrm{O}_{3}-0.1 \mathrm{TiO}_{2}$ ceramics.

\begin{tabular}{cccc}
\hline Heat Treatment & $\begin{array}{c}\mathbf{Q} \cdot f \\
(\mathbf{G H z})\end{array}$ & $\boldsymbol{\varepsilon}_{\mathbf{r}}$ & $\begin{array}{c}\boldsymbol{\tau}_{\mathbf{f}} \\
\left(\mathbf{p p m} /{ }^{\circ} \mathbf{C}\right)\end{array}$ \\
\hline $1400{ }^{\circ} \mathrm{C}$ as-sintered & 62,000 & 11.9 & -39.3 \\
$1400{ }^{\circ} \mathrm{C}$ post annealed & 93,000 & 12.7 & -6.8 \\
$1500^{\circ} \mathrm{C}$ as-sintered & 71,000 & 11.7 & -48.7 \\
$1500{ }^{\circ} \mathrm{C}$ post annealed & 102,000 & 12.6 & -4.5 \\
$1550{ }^{\circ} \mathrm{C}$ as-sintered & 82,000 & 11.8 & -50.2 \\
$1550{ }^{\circ} \mathrm{C}$ post annealed & 111,000 & 12.4 & +1.2 \\
$1600^{\circ} \mathrm{C}$ as-sintered & 80,000 & 11.9 & -51.3 \\
$1600^{\circ} \mathrm{C}$ post annealed & 104,000 & 12.3 & +1.4 \\
\hline
\end{tabular}

Figure $6 \mathrm{~b}$ shows that the $\varepsilon_{\mathrm{r}}$ of the $0.9 \mathrm{Al}_{2} \mathrm{O}_{3}-0.1 \mathrm{TiO}_{2}$ system is larger than that of the pure $\mathrm{Al}_{2} \mathrm{O}_{3}$, while the $\varepsilon_{\mathrm{r}}$ of the post-annealed sample is increased compared with the as-sintered sample. It can be seen from Table 2 that the dielectric constant of the $0.9 \mathrm{Al}_{2} \mathrm{O}_{3}-0.1 \mathrm{TiO}_{2}$ system after annealing at different temperatures is essentially unchanged, all are around 12.5 .

Figure $6 \mathrm{c}$ shows the variation of the $\tau_{\mathrm{f}}$ of the $0.9 \mathrm{Al}_{2} \mathrm{O}_{3}-0.1 \mathrm{TiO}_{2}$ system at different temperatures. With the increase in temperature, the $\tau_{\mathrm{f}}$ of pure $\mathrm{Al}_{2} \mathrm{O}_{3}$ remains basically unchanged, which is approximately equal to $-60 \mathrm{ppm} /{ }^{\circ} \mathrm{C}$. The sample after annealing has a larger improvement than the as-sintered in the $\tau_{\mathrm{f}}$, and the value of $\tau_{\mathrm{f}}$ differs by more than $30 \mathrm{ppm} /{ }^{\circ} \mathrm{C}$. After annealing at $1550{ }^{\circ} \mathrm{C}$, the $\tau_{\mathrm{f}}$ of the sample is $+1.2 \mathrm{ppm} /{ }^{\circ} \mathrm{C}$, which is the closest to zero. 


\subsection{The Results of S Parameters and Group Delay of the Filter}

The aforementioned dielectric properties of $0.9 \mathrm{Al}_{2} \mathrm{O}_{3}-0.1 \mathrm{TiO}_{2}$ at different temperatures indicates that when sintered at $1550{ }^{\circ} \mathrm{C}$ for $2 \mathrm{~h}$ and annealed at $1000{ }^{\circ} \mathrm{C}$ for $5 \mathrm{~h}$, the composite material exhibits the best performance. The DLP-manufactured filter was treated by this process.

Figure 7a shows the differences of insertion loss (IL) and return loss (RL) of the microwave dielectric ceramic filter between the actual measurement and electromagnetic simulation. The center frequency of the filter was set to be $8.3 \mathrm{GHz}$ in the electromagnetic simulation whereas the measured center frequency deviates from the center frequency by $0.05 \mathrm{GHz}$, that is the $\Delta \mathrm{f}=0.6 \%$. As shown in Figure 7a, the IL in the passband of $8.24-8.37 \mathrm{GHz}$ in the actual measurement is $1.16-2.52 \mathrm{~dB}$, which is 1.15-2.49 dB higher than the simulated one. The measured S11 curve shows that the RL is greater than $30 \mathrm{~dB}$ in the passband, meeting the performance specifications required for this type of filter. The passband group delay of the filter is plotted in Figure $7 \mathrm{~b}$. The actual measurement results show that the group delay in the $3 \mathrm{~dB}$ bandwidth $(8.24-8.37 \mathrm{GHz})$ of the passband is $0.87-1.48 \mathrm{~ns}$. Figure $7 \mathrm{c}$ indicates that it has good isolation and output RL in actual measurement.

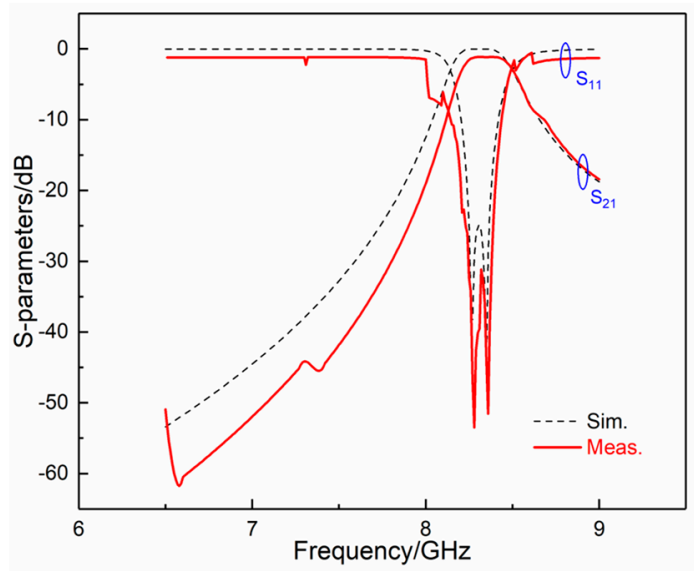

(a)

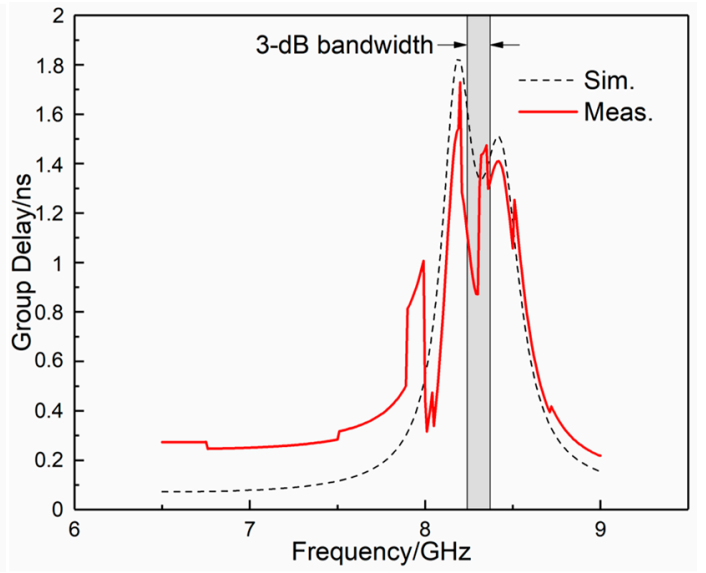

(b)

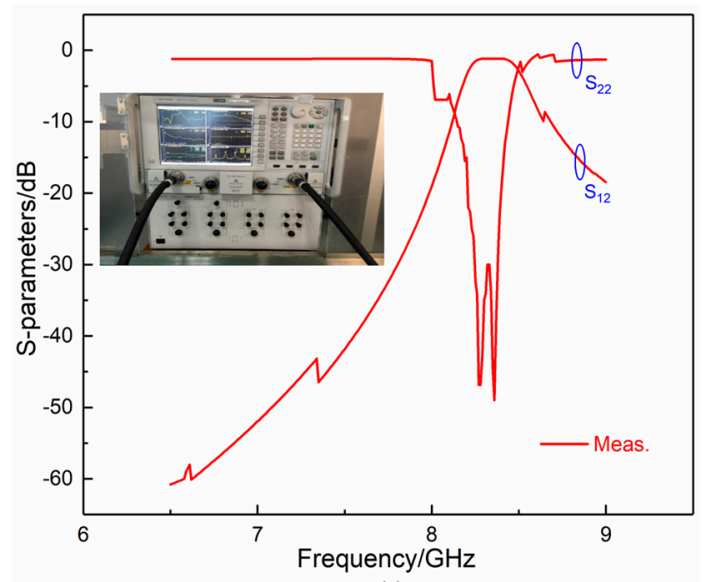

(c)

Figure 7. (a) Wideband responses of the S11 and S21 parameters. (b) Passband group delay. (c) Measured wideband responses of the S12 and S22 parameters. The inset shows the photograph of the network analyzer. 


\section{Discussion}

\subsection{Discussion of the Dielectric Properties}

The quality of the microstructure has a great influence on the dielectric properties of microwave dielectric ceramics. Figure $8(\mathrm{a} 1)$ shows that when the sintering temperature is $1400{ }^{\circ} \mathrm{C}$, the as-sintered sample has different grain sizes and no obvious grain boundaries. However, as is shown in Figure 8(b1), the grains of the annealed sample are improved and the surface pores are reduced. When the sintering temperature rises, the grain size tends to be uniform and the surface pores gradually reduce in number and size. When the sintering temperature rises to $1600{ }^{\circ} \mathrm{C}$, some grains are excessively grown due to over burning. It can be observed in Figure 8(a3,b3) that when the sample is sintered at $1550{ }^{\circ} \mathrm{C}$ for $2 \mathrm{~h}$ and annealed at $1000{ }^{\circ} \mathrm{C}$ for $5 \mathrm{~h}$, the surface is regular, the grain distribution is uniform, the pores on the surface are small, and the grain boundaries are more obvious. This further verified that the 0.9 $\mathrm{Al}_{2} \mathrm{O}_{3}-0.1 \mathrm{TiO}_{2}$ system shown in Figure 6 has the best dielectric properties when sintered at $1550{ }^{\circ} \mathrm{C}$ for $2 \mathrm{~h}$ and post annealed at $1000{ }^{\circ} \mathrm{C}$ for $5 \mathrm{~h}$.

The Qf value of $0.9 \mathrm{Al}_{2} \mathrm{O}_{3}-0.1 \mathrm{TiO}_{2}$ first increases and then decreases with the increase in the sintering temperature, which is the result of increasing density and the appearance of secondary phase $\mathrm{Al}_{2} \mathrm{TiO}_{5}$. The $\mathrm{Qf}$ value of $\mathrm{TiO}_{2}$ is $500,000 \mathrm{~Hz}$, which is one order of magnitude lower than that of $\mathrm{Al}_{2} \mathrm{O}_{3}\left(\mathrm{Qf}=5,000,000 \mathrm{~Hz}\right.$ ). The $0.9 \mathrm{Al}_{2} \mathrm{O}_{3}-0.1 \mathrm{TiO}_{2}$ system can be regarded as adding $\mathrm{TiO}_{2}$ to the $\mathrm{Al}_{2} \mathrm{O}_{3}$ system. Firstly, with the addition of $\mathrm{TiO}_{2}$, the $\mathrm{Qf}$ value of the system must be lower than the $\mathrm{Qf}$ value of $\mathrm{Al}_{2} \mathrm{O}_{3}$. As shown in Figure 9, as the sintering temperature gradually increased, the relative density of the sample becomes increasingly higher, reaching a maximum at $1550{ }^{\circ} \mathrm{C}$. Owing to the densification of the material, the tighter the ion binding is, the more difficult the ion movement is. As such, it is difficult for ion relaxation polarization to occur. Overall, there is no polarization loss, except for the electronic and ionic elastic displacement polarization. In addition, when the material is denser, there are fewer pores, thus resulting in the smaller ionization loss caused by gas ionization in the pores. Combining the above two factors, the Qf value first increases. However, when the sintering temperature reaches $1600{ }^{\circ} \mathrm{C}$, some individual particles grow abnormally because of over burning, causing structural defects, which is the main reason for the decrease in the Qf value. Under the joint influence of these factors, the Qf value of the $0.9 \mathrm{Al}_{2} \mathrm{O}_{3}-0.1 \mathrm{TiO}_{2}$ system first increases and then decreases with the increase of sintering temperature.

However, the Qf value of the as-sintered sample is lower than that of the annealed one at the same temperature. The reason for this is that the formation of the high loss phase $\mathrm{Al}_{2} \mathrm{TiO}_{5}$ reduces the Qf value of the system. It can be observed in Figure 10 that in addition to the diffraction peaks of the two phases of $\mathrm{Al}_{2} \mathrm{O}_{3}$ and $\mathrm{TiO}_{2}$, the diffraction peaks of $\mathrm{Al}_{2} \mathrm{TiO}_{5}$ appear at different sintering temperatures, indicating that $\mathrm{Al}_{2} \mathrm{O}_{3}$ reacts with $\mathrm{TiO}_{2}$ to form $\mathrm{Al}_{2} \mathrm{TiO}_{5}$ during sintering. The sample annealed at $1000{ }^{\circ} \mathrm{C}$ for $5 \mathrm{~h}$ showed only two phases of $\mathrm{Al}_{2} \mathrm{O}_{3}$ and $\mathrm{TiO}_{2}$ in the $\mathrm{XRD}$ pattern, signifying that the $\mathrm{Al}_{2} \mathrm{TiO}_{5}$ phase was decomposed by annealing treatment. According to Figure 4, when the 0.9 $\mathrm{Al}_{2} \mathrm{O}_{3}-0.1 \mathrm{TiO}_{2}$ system was sintered at $1450{ }^{\circ} \mathrm{C}, 1500{ }^{\circ} \mathrm{C}, 1550{ }^{\circ} \mathrm{C}$, and $1600{ }^{\circ} \mathrm{C}$ for $2 \mathrm{~h}$, and annealed at $1000^{\circ} \mathrm{C}$ for $5 \mathrm{~h}$, the composition of the phases was roughly the same. 


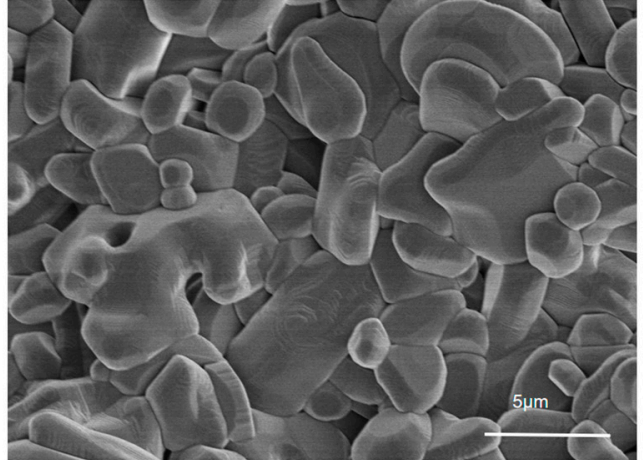

(a1)

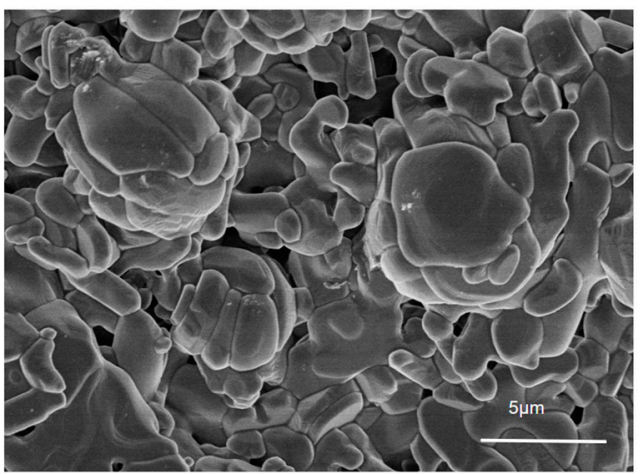

(a2)

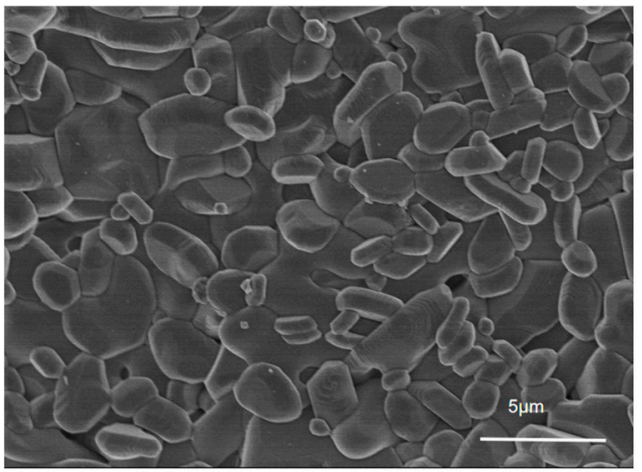

(a3)

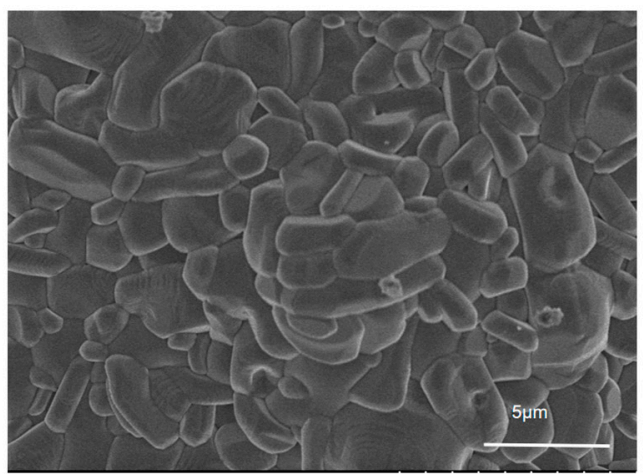

(a4)

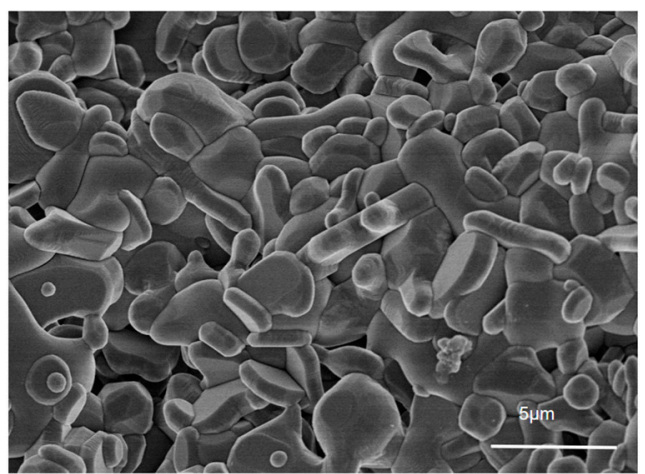

(b1)

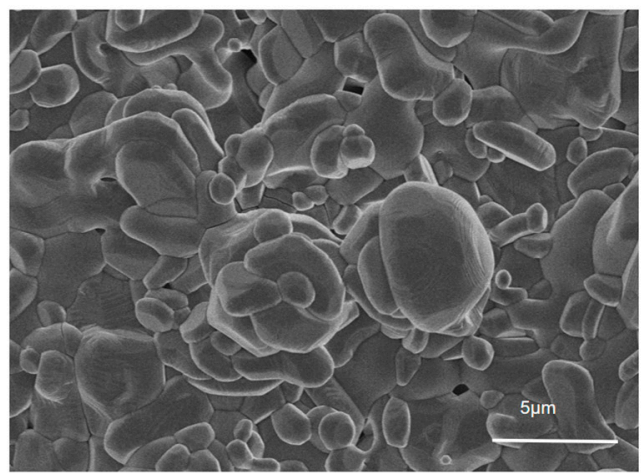

(b2)

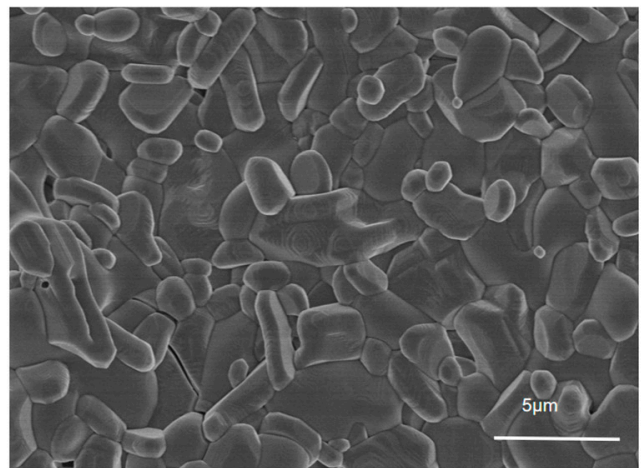

(b3)

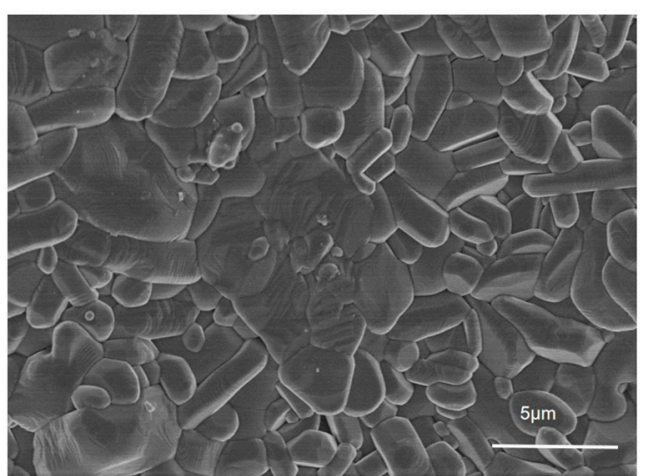

(b4)

Figure 8. SEM images of $0.9 \mathrm{Al}_{2} \mathrm{O}_{3}-0.1 \mathrm{TiO}_{2}$ ceramics sintered at (a1) $1400{ }^{\circ} \mathrm{C},(\mathbf{a} 2) 1500{ }^{\circ} \mathrm{C},(\mathbf{a} 3) 1550{ }^{\circ} \mathrm{C}$, (a4) $1600{ }^{\circ} \mathrm{C}$. (b1-b4) are post-annealed samples of (a1-a4), respectively. 


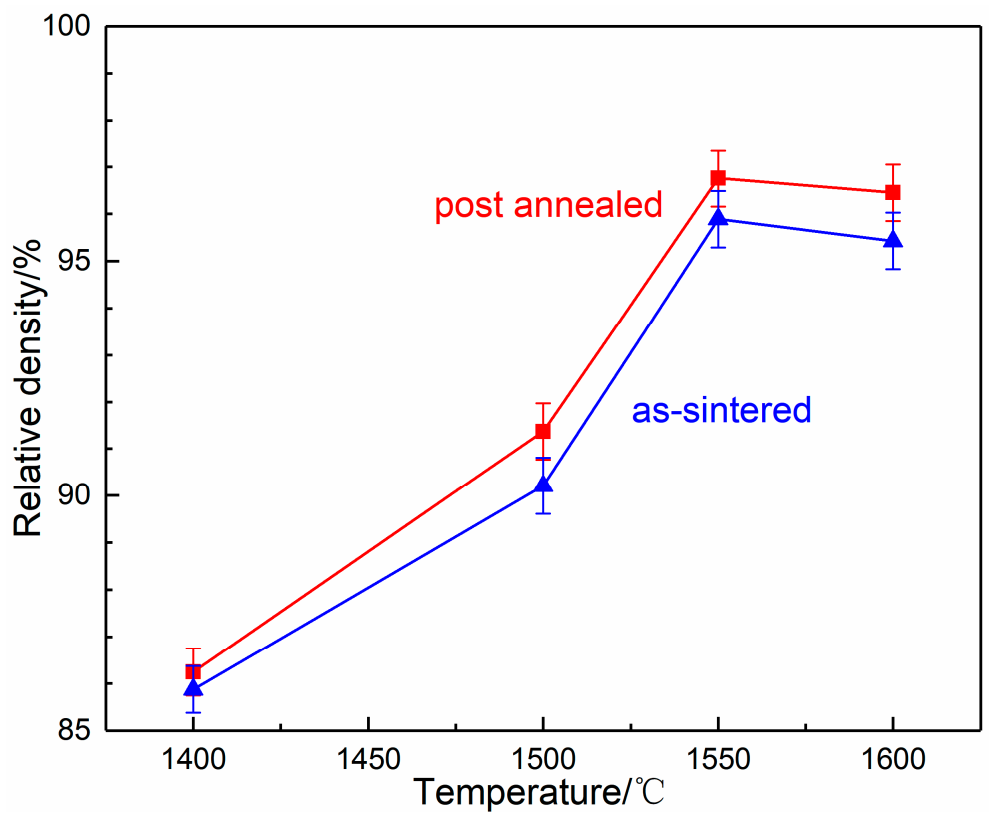

Figure 9. Relative density of $0.9 \mathrm{Al}_{2} \mathrm{O}_{3}-0.1 \mathrm{TiO}_{2}$ ceramics sintered at different sintering temperatures and annealed at $1000{ }^{\circ} \mathrm{C}$ for $5 \mathrm{~h}$.

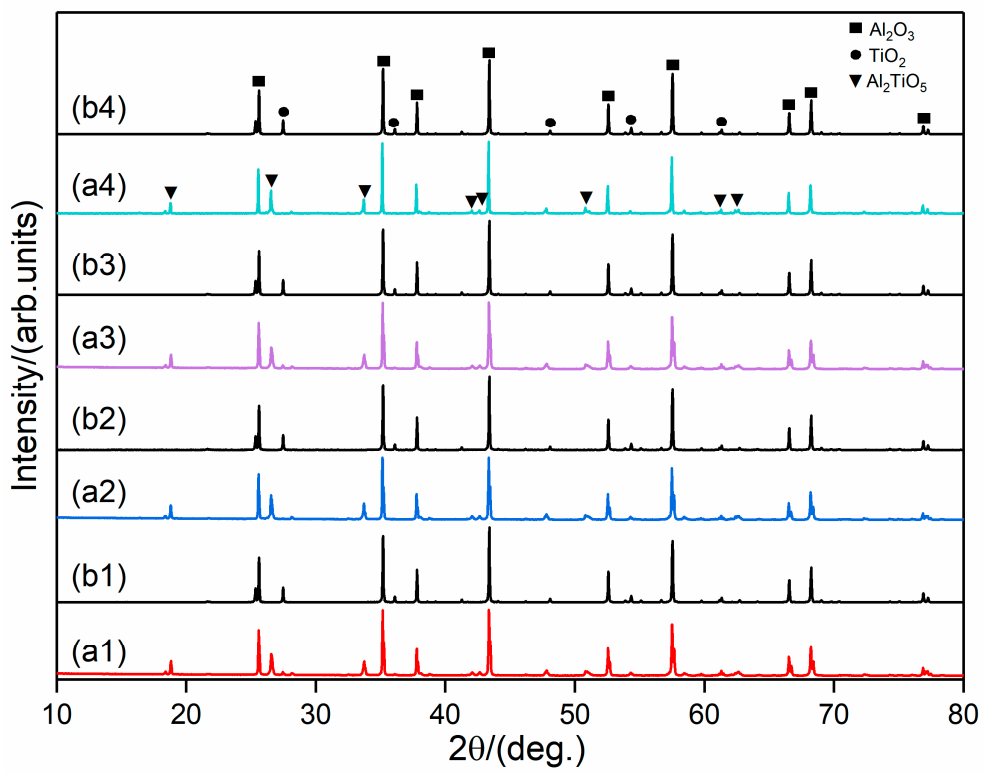

Figure 10. XRD patterns of $0.9 \mathrm{Al}_{2} \mathrm{O}_{3}-0.1 \mathrm{TiO}_{2}$ samples sintered at (a1) $1400^{\circ} \mathrm{C},(\mathbf{a} 2) 1500{ }^{\circ} \mathrm{C},(\mathbf{a} 3) 1550{ }^{\circ} \mathrm{C}$, and (a4) $1600{ }^{\circ} \mathrm{C}$. (b1-b4) are post-annealed samples of (a1-a4), respectively.

Since $\varepsilon_{\mathrm{r}}=10$ of $\mathrm{Al}_{2} \mathrm{O}_{3}$ and $\varepsilon_{\mathrm{r}}=100$ of $\mathrm{TiO}_{2}$, the $\varepsilon_{\mathrm{r}}$ of the system is bound to increase with the addition of $\mathrm{TiO}_{2}$. As shown in Figure 4, when the sintering temperature is higher than $1200{ }^{\circ} \mathrm{C}$ and annealing is not performed, the secondary phase $\mathrm{Al}_{2} \mathrm{TiO}_{5}$ is formed in the $0.9 \mathrm{Al}_{2} \mathrm{O}_{3}-0.1 \mathrm{TiO}_{2}$ system. However, the $\varepsilon_{\mathrm{r}}$ value of the $\mathrm{Al}_{2} \mathrm{TiO}_{5}$ is 3.4, which is lower than that of the main phase. Annealing at $1000{ }^{\circ} \mathrm{C}$ for $5 \mathrm{~h}$ results in the decomposition of $\mathrm{Al}_{2} \mathrm{TiO}_{5}$ with low $\varepsilon_{\mathrm{r}}$ and the precipitation of $\mathrm{TiO}_{2}$ with high $\varepsilon_{\mathrm{r}}$, so the $\varepsilon_{\mathrm{r}}$ of the annealed sample is increased compared to the as-sintered one.

According to microscopic analysis, the $\varepsilon_{\mathrm{r}}$ is a macroscopic physical quantity that comprehensively reflects the polarization behavior of the dielectric. When the polarizing ability of the dielectric under the electric field is stronger, the $\varepsilon_{\mathrm{r}}$ is larger. By Clausius equation

$$
P=N \alpha E i
$$


where $P$ : macroscopic polarizability, $\alpha$ : microscopic polarizability, $N$ : number of molecules per unit volume of dielectric, Ei: effective electric field, and E: average macroscopic electric field. So:

$$
\varepsilon_{\mathrm{r}}=1+\frac{N \alpha}{\varepsilon_{0}} \bullet \frac{E i}{E}
$$

It can be estimated from Formula (3) that there are three ways to increase $\varepsilon_{\mathrm{r}}$. The first method is to increase the value of $N$, that is, to increase the density of the dielectric materials. The second method is to adopt dielectric materials composed of plasmids that have a large polarization $\alpha$. The last method is by selecting material that have a large effective electric field $E i$. The $\varepsilon_{\mathrm{r}}$ of the $\mathrm{Al}_{2} \mathrm{O}_{3}$ system mainly depends on the ion polarization, which is predominantly determined by the polarization mode of the lattice vibration. According to RD Shannon [20], the polarizability of $\mathrm{Al}^{3+}$ ions is $0.78 \times 10^{-40} \mathrm{C} \cdot \mathrm{m}^{2} \cdot \mathrm{V}^{-1}$, and the polarization of $\mathrm{Ti}^{4+}$ ions is $2.94 \times 10^{-40} \mathrm{C} \cdot \mathrm{m}^{2} \cdot \mathrm{V}^{-1}$, which further proves that the introduction of $\mathrm{Ti}^{4+}$ ions will increase the $\varepsilon_{\mathrm{r}}$ of the $0.9 \mathrm{Al}_{2} \mathrm{O}_{3}-0.1 \mathrm{TiO}_{2}$ system.

The $\varepsilon_{\mathrm{r}}$ of the material satisfies the formula:

$$
\frac{1}{\varepsilon_{r}}=\frac{1}{\varepsilon_{g}}+\frac{1}{R \varepsilon_{g b}}
$$

where $\varepsilon_{g}$ and $\varepsilon_{g b}$ are the dielectric constants of the grain and the grain boundary layer, respectively, and $\mathrm{R}$ is the ratio of the thickness of the grain to grain boundary layer $(\mathrm{Dg} / \mathrm{Dgb})$. It can be determined from Figure 8 that as the sintering temperature increases, the pores decrease and the unit cell volume increases, which is beneficial to the intracellular ion vibration. Further, the polarization is enhanced, resulting in an increase in the dielectric constant $\varepsilon_{g}$ of the grain and the dielectric constant $\varepsilon_{g b}$ of the grain boundary layer. During the densification of the microstructure, the crystal grains grow uniformly, and the grain boundary layers become thinner, causing $R$ to increase. According to Formula $(4), \varepsilon_{r}$ is thereby increased.

According to the Lichnetecker Law, the $\tau_{\mathrm{f}}$ of $\mathrm{Al}_{2} \mathrm{O}_{3}$ is negative, $-60 \mathrm{ppm} /{ }^{\circ} \mathrm{C}$, while the $\tau_{\mathrm{f}}$ of $\mathrm{TiO}_{2}$ is positive, approximately $450 \mathrm{ppm} /{ }^{\circ} \mathrm{C}$ [21]. With the addition of $\mathrm{TiO}_{2}$, the $\tau_{\mathrm{f}}$ of the system drifts positively, and $\tau_{\mathrm{f}} \approx 0$ when annealed at $1550{ }^{\circ} \mathrm{C}$. The $\tau_{\mathrm{f}}$ value of pure $\mathrm{Al}_{2} \mathrm{O}_{3}$ ceramics is not affected by the sintering temperature. The $\tau_{\mathrm{f}}$ of the as-sintered $0.9 \mathrm{Al}_{2} \mathrm{O}_{3}-0.1 \mathrm{TiO}_{2}$ ceramics is about $-45 \mathrm{ppm} /{ }^{\circ} \mathrm{C}$, which is attributable to the reaction of $\mathrm{TiO}_{2}$ and $\mathrm{Al}_{2} \mathrm{O}_{3}$ at high temperature to form the second phase $\mathrm{Al}_{2} \mathrm{TiO}_{5}$. As a result of the reduction of $\mathrm{TiO}_{2}$ content in the system, the negative $\tau_{\mathrm{f}}$ of $\mathrm{Al}_{2} \mathrm{O}_{3}$ ceramics is not corrected too much. When adopting post-annealment, the $\mathrm{Al}_{2} \mathrm{TiO}_{5}$ phase decomposes and the amount of $\mathrm{TiO}_{2}$ increases. The $\tau_{\mathrm{f}}$ value of the $0.9 \mathrm{Al}_{2} \mathrm{O}_{3}-0.1 \mathrm{TiO}_{2}$ system changes from negative to positive. As shown in Table 2 , the $\tau_{\mathrm{f}}$ value of $1.2 \mathrm{ppm} /{ }^{\circ} \mathrm{C}$ was obtained after being annealed at $1550{ }^{\circ} \mathrm{C}$.

\subsection{Error Analysis of the Simulated and Measured Results of the Microwave Dielectric Ceramic Filter}

Figure 7 presents the measured results compared with the simulation results. The measured center frequency was shifted backward by $0.05 \mathrm{GHz}$, which is caused by the uncertainty of the shrinkage of the ceramic sample after debinding and sintering. According to the previous measurements, after the body was sintered, the linear shrinkage was about $25 \%$, so the model is enlarged to 1.34 times of the original size. However, the size of the filter will deviate slightly after sintering. For example, although the actual measurement shows that the wall thickness is $1.15 \mathrm{~mm}$, the wall thickness of the sintered filter is expected to be $1 \mathrm{~mm}$. For such reasons, the results of the measurement may deviate from the simulation results. Compared with the simulation results, the actual measured IL and RL are a little large. This is attributable to the fact that, in addition to the manufacturing errors mentioned above, the influence of the layer thickness and quality of the metal layer on the measurement is also considered. It should be noted that this was not taken into account during the electromagnetic simulation process. 


\section{Conclusions}

In this paper, DLP AM technology and microwave dielectric ceramic material were utilized to fabricate a monolithic microwave dielectric ceramic filter with a complex and precious structure. When sintered at $1550{ }^{\circ} \mathrm{C}$ for $2 \mathrm{~h}$ and post annealed at $1000^{\circ} \mathrm{C}$ for $5 \mathrm{~h}$, the obtained dielectric properties of the $0.9 \mathrm{Al}_{2} \mathrm{O}_{3}-0.1 \mathrm{TiO}_{2}$ system were the best: $\varepsilon_{\mathrm{r}}=12.4, \mathrm{Q} \times \mathrm{f}=111,000 \mathrm{GHz}$, and $\tau_{\mathrm{f}}=+1.2 \mathrm{ppm} /{ }^{\circ} \mathrm{C}$. The measured value of the central frequency deviates from that of the simulated central frequency by $0.05 \mathrm{GHz}$, that is, the $\Delta \mathrm{f}=0.6 \%$. The actual IL value is $1.16-2.52 \mathrm{~dB}$ in the passband of $8.24-8.37 \mathrm{GHz}$ and the actual RL value is greater than $30 \mathrm{~dB}$, satisfying the design requirements of this type of filter. This work provides an effective method for manufacturing monolithic microwave dielectric ceramic filters with complex and precious structures, which can be widely used in cellular mobile network systems, communication base stations, television satellite receiving systems, satellite communication, and radar systems, etc. By controlling the composition of the ceramic material and improving the quality of the metalization coating, the dielectric properties of the ceramic material can be further optimized and the applicable frequency band of the filter can be further improved.

Author Contributions: Conceptualization, Q.L. and L.S.; investigation, C.J. and D.X.; methodology, Y.Y. and M.X.; writing-original draft preparation, Q.L.; writing—review and editing, C.W., M.Q. and J.Z.

Funding: This research was funded by the National Key Research and Development Program "Additive Manufacturing and Laser Manufacturing" (Grant No. 2018YFB1105400 and 2018YFB1105801), National Natural Science Foundation of China (Grant No.U1537105 and No.U1532106) and National Key Laboratory of Science and Technology on Helicopter Transmission (Nanjing University of Aeronautics and Astronautics) (Grant No. HTL-A-19G011).

Conflicts of Interest: The authors declare no conflict of interest.

\section{References}

1. Raveendran, A.; Sebastian, M.T.; Raman, S. Applications of Microwave Materials: A Review. J. Electron. Mater. 2019, 48, 2601-2634. [CrossRef]

2. Sebastian, M.T.; Ubic, R.; Jantunen, H. Low-loss dielectric ceramic materials and their properties. Int. Mater. Rev. 2015, 60, 392-412. [CrossRef]

3. Partridge, G. Inorganic materials V. Ceramic materials possessing high thermal conductivity. Adv. Mater. 1992, 4, 51-54. [CrossRef]

4. Alford, N.M.; Penn, S.J. Sintered alumina with low dielectric loss. J. Appl. Phys. 1996, 80, 5895-5898. [CrossRef]

5. Templeton, A.; Wang, X.; Penn, S.J.; Webb, S.J.; Cohen, L.F.; Alford, N.M. Microwave Dielectric Loss of Titanium Oxide. J. Am. Ceram. Soc. 2000, 83, 95-100. [CrossRef]

6. Ohishi, Y.; Miyauchi, Y.; Ohsato, H.; Kakimoto, K.-I. Controlled Temperature Coefficient of Resonant Frequency of $\mathrm{Al}_{2} \mathrm{O}_{3}-\mathrm{TiO}_{2}$ Ceramics by Annealing Treatment. Jpn. J. Appl. Phys. 2004, 43, 749-751. [CrossRef]

7. Roshni, S.B.; Sebastian, M.T.; Surendran, K.P. Can zinc aluminate-titania composite be an alternative for alumina as microelectronic substrate? Sci. Rep. 2017, 7. [CrossRef] [PubMed]

8. Dimitriadis, A.I.; Debogovic, T.; Favre, M.; Billod, M.; Barloggio, L.; Ansermet, J.-P.; Rijk, D.E. Polymer-Based Additive Manufacturing of High-Performance Waveguide and Antenna Components. Proc. IEEE 2017, 105, 668-676. [CrossRef]

9. Auria, M.D.; Otter, W.J.; Hazell, J.; Gillatt, B.T.W.; Long-Collins, C.; Ridler, N.M.; Lucyszyn, S. 3-D Printed Metal-Pipe Rectangular Waveguides. IEEE Trans. Compon. Packag. Manuf. Technol. 2015, 5, 1339-1349. [CrossRef]

10. Liu, B.; Gong, X.; Chappell, W.J. Applications of layer-by-layer polymer stereolithography for three-dimensional high-frequency components. IEEE Trans. Microwave Theory Tech. 2004, 52, 2567-2575. [CrossRef]

11. Guo, C.; Shang, X.; Lancaster, M.J.; Xu, J. A 3-D Printed Lightweight X-Band Waveguide Filter Based on Spherical Resonators. IEEE Microwave Wireless Compon. Lett. 2015, 25, 442-444. [CrossRef]

12. Zocca, A.; Colombo, P.; Gomes, C.M.; Günster, J. Additive Manufacturing of Ceramics: Issues, Potentialities, and Opportunities. J. Am. Ceram. Soc. 2015, 98, 1983-2001. [CrossRef] 
13. Zeng, Y.; Yan, Y.; Yan, H.; Liu, C.; Li, P.; Dong, P.; Zhao, Y.; Chen, J. 3D printing of hydroxyapatite scaffolds with good mechanical and biocompatible properties by digital light processing. J. Mater. Sci. 2018, 53, 6291-6301. [CrossRef]

14. He, R.; Liu, W.; Wu, Z.; An, D.; Huang, M.; Wu, H.; Jiang, Q.; Ji, X.; Wu, S.; Xie, Z. Fabrication of complex-shaped zirconia ceramic parts via a DLP- stereolithography-based 3D printing method. Ceram. Int. 2018, 44, 3412-3416. [CrossRef]

15. Liu, Z.; Liang, H.; Shi, T.; Xie, D.; Chen, R.; Han, X.; Shen, L.; Wang, C.; Tian, Z. Additive manufacturing of hydroxyapatite bone scaffolds via digital light processing and in vitro compatibility. Ceram. Int. 2019, 45, 11079-11086. [CrossRef]

16. Zaman, A.A.; Dutcher, C.S. Viscosity of Electrostatically Stabilized Dispersions of Monodispersed, Bimodal, and Trimodal Silica Particles. J. Am. Ceram. Soc. 2006, 89, 422-430. [CrossRef]

17. Zhou, M.; Liu, W.; Wu, H.; Song, X.; Chen, Y.; Cheng, L.; He, F.; Chen, S.; Wu, S. Preparation of a defect-free alumina cutting tool via additive manufacturing based on stereolithography-Optimization of the drying and debinding processes. Ceram. Int. 2016, 42, 11598-11602. [CrossRef]

18. Hakki, B.W.; Coleman, P.D. A Dielectric Resonator Method of Measuring Inductive Capacities in the Millimeter Range. IEEE Trans. Microwave Theory Tech. 1960, 8, 402-410. [CrossRef]

19. Kobayashi, Y.; Katoh, M. Microwave Measurement of Dielectric Properties of Low-Loss Materials by the Dielectric Rod Resonator Method. IEEE Trans. Microwave Theory Tech. 1985, 33, 586-592. [CrossRef]

20. Shannon, R.D. Dielectric polarizabilities of ions in oxides and fluorides. J. Appl. Phys. 1993, 73, 348-366. [CrossRef]

21. Kobayashi, Y.; Aoki, T.; Kabe, Y. Influence of Conductor Shields on the Q-Factors of a TEO Dielectric Resonator. IEEE Trans. Microwave Theory Tech. 1985, 33, 1361-1366. [CrossRef]

(C) 2019 by the authors. Licensee MDPI, Basel, Switzerland. This article is an open access article distributed under the terms and conditions of the Creative Commons Attribution (CC BY) license (http://creativecommons.org/licenses/by/4.0/). 